\title{
REVIEW: DAIRY FARM ELECTRICITY USE, CONSERVATION, AND RENEWABLE PRODUCTION- A GLOBAL PERSPECTIVE
}

\author{
Ahmad Mohsenimanesh ${ }^{1}$, Etienne L. LeRiche ${ }^{2}$, Robert Gordon ${ }^{3}$, Steve Clarke ${ }^{4}$, \\ Ronald D. MacDonald ${ }^{5}$, Ian MacKinnon ${ }^{6}$, Andrew C. VanderZaag7,** \\ ${ }^{1}$ CanmetEnergy, Ottawa, Ontario, Canada. \\ 2 Agriculture and Agri-Food Canada-ORDC, Ottawa, Ontario, Canada. \\ ${ }^{3}$ University of Windsor, Windsor, Ontario, Canada. \\ ${ }^{4}$ OMAFRA, Kemptville, Ontario, Canada. \\ ${ }^{5}$ Agviro, Inc., Guelph, Ontario, Canada. \\ ${ }^{6}$ Wood Plc., Cambirdge, Ontario, Canada. \\ ${ }^{7}$ Agriculture and Agri-Food Canada, Science and Technology Branch, Ottawa, Ontario, Canada. \\ * Correspondence: andrew.vanderzaag@agr.gc.ca.
}

\section{Highlights}

- Studies of electricity use were reviewed, representing five continents.

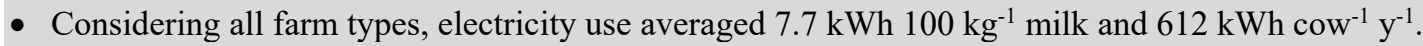

- Pasture-based dairy systems used less electricity than barn-based systems (475 vs. $\left.769 \mathrm{kWh} \mathrm{cow}^{-1} \mathrm{y}^{-1}\right)$.

- By combining several conservation technologies there is potential to reduce electricity demand by one-third.

- Dairy farms can reach net zero electricity by combining renewable energy production with conservation.

\begin{abstract}
This review summarizes electricity use on dairy farms, with a focus on how energy is used, energy use indices (EUI), conservation strategies, and generation of renewable energy to reach net zero. EUI of electricity consumption varied between the identified studies primarily based on farm management system (confined, pasture-based), housing type (tiestall, free-stall), and region (North America, Europe, Asia, Africa, Oceania). The highest electricity usage was associated with milking and milk cooling systems, which, on average, accounted for $23 \%$ and $22 \%$ of total electricity use, respectively. Energy use scaled per cow $\left(E U I_{c}\right)$ was lower, on average, for pasture-based dairy systems than for confined systems (475 vs.

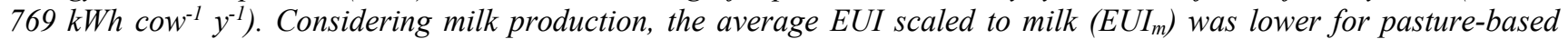
systems (6.6 kWh $\left.100 \mathrm{~kg}^{-1}\right)$ than for confined systems $9.2 \mathrm{kWh} 100 \mathrm{~kg}^{-1}$. Considering all non-irrigated farm types, EUI averaged $7.7 \mathrm{kWh} 100 \mathrm{~kg}^{-1}$ and EUI averaged $612 \mathrm{kWh} \mathrm{cow}^{-1} \mathrm{y}^{-1}$. There was a large range of EUI, with higher values associated with automated milking systems and irrigation. Electricity consumption by the global dairy sector (excluding irrigation) was estimated using the average EUIm at approximately 64.2 TWh $y^{-1}$. The main conservation technologies include variable speed drives (milk vacuum pumps, milking systems, fans), pre-cool heat exchangers, refrigeration heat recovery systems, energy-efficient light fixtures (compact fluorescents, light emitting diodes), and efficient ventilation (highvolume low-speed fans). Theoretical savings of up to $32 \%$ overall could be achieved by combining several technologies. Feedback from electricity monitoring can inform dairy farmers of their energy use pattern to guide decisions to reduce consumption. Tools for predicting energy use and related costs on dairy farms, which can indicate potential energy savings from operational changes, were reviewed. By combining conservation methods with renewable energy from biogas or solar, many dairy farms can produce enough electricity to reach net zero electricity. For example, a hypothetical barn-based 250 milking-cow dairy farm consumed $1021 \mathrm{kWh} \mathrm{cow}^{-1} \mathrm{y}^{-1}$, on average, and could produce approximately $1095 \mathrm{kWh}^{\mathrm{cow}} \mathrm{w}^{-1}$ $y^{-1}$ using a biodigester or $960 \mathrm{kWh} \mathrm{cow}^{-1} \mathrm{y}^{-1}$ using rooftop photovoltaic solar panels.
\end{abstract}

Keywords. Conservation, Dairy footprint, Electricity use, Electricity partitioning, Energy utilization index, Renewable energy.

\footnotetext{
(c) $(1) \ominus$ The authors have paid for open access for this article. This work is licensed under a Creative Commons AttributionNonCommercial-NoDerivatives 4.0 International License https://creative commons.org/licenses/by-nc-nd/4.0/

Submitted for review on 5 April 2021 as manuscript number ES 14621; approved for publication as a Review Article by the Energy Systems Community of ASABE on 25 August 2021.
}

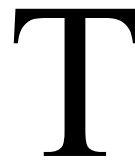

he world's population is expected to reach roughly 9.8 billion by 2050 (UN, 2017). As a result, the demand for food production will increase. Global dairy production was more than 850 million tonnes of fluid milk in 2019 (FAO, 2020), and it is expected to increase in the coming decades. Projections from 2006 predict a roughly $55 \%$ increase in the consumption of dairy 
products by 2050 (FAO, 2006, 2011). Energy on dairy operations is used both directly (fuel, electricity) and indirectly (fertilizer, chemicals) (Schnepf, 2004). Indirect energy use typically makes up $55 \%$ to $70 \%$ of the total energy requirements of dairy farms (Upton et al., 2013; Houston et al., 2014; Podstolski, 2016). On-farm direct energy use has been estimated to make up $12 \%$ to $16 \%$ of total energy in rain-fed systems (Bailey et al., 2008; Upton et al., 2013; Shine et al., $2018 \mathrm{a}, 2018 \mathrm{~b}$ ) and up to roughly $30 \%$ on farms with intensive irrigation (Podstolski, 2016). Electricity use in agriculture has been estimated to be roughly $3 \%$ of total energy use in the Unites States and 2.7\% in the European Union (Slocombe et al., 1992; Eurostat, 2018). In Canada, the dairy industry is responsible for an estimated $10 \%$ of total agricultural electricity use (Khakbazan, 2000). These aggregate figures, although useful, are often based on a number of generalizations and assumptions. In many cases, there have not been systematic assessments of electricity use from different farm components - or of changes in energy use as a result of management or technology - and there is a need to present a summary of current knowledge.

Electricity utilization on dairy farms has been identified as an area where significant savings and optimization can be achieved (Kammel and Patoch, 1993; Peebles et al., 1994; EnSave, 2015). Conserving electricity can reduce potential air pollution, and can reduce the carbon footprint of milk production (Pervanchon et al., 2002; Christie et al., 2012; EnSave, 2015; Wang et al., 2018). In addition, the cost of electricity is a concern for dairy operations, and increased efficiency could lead to financial savings (Upton et al., 2014b). The amount of the savings depends on electricity rates, which vary considerably across regions, e.g., 0.05 to $0.25 \mathrm{USD} \mathrm{kWh}^{-1}$ in North America (HydroQuebec, 2018), roughly $0.12 \mathrm{USD} \mathrm{kWh}^{-1}$ in the European Union (Eurostat, 2019), 0.16 to 0.27 USD $\mathrm{kWh}^{-1}$ in New Zealand (figure.nz, 2019), and approximately $0.10 \mathrm{USD} \mathrm{kWh}^{-1}$ in China (CEIC, 2019).

Beyond energy efficiency, there is growing interest in the concept of net zero energy, whereby a facility produces as much on-site electricity as it uses. This concept comes from the field of building sciences and combines energy conservation with the production of renewables to achieve this goal (Marszal et al., 2011). Within the dairy farming context, renewable technologies that have the potential to enable farms to achieve net zero electricity are discussed, specifically anaerobic digestion and solar. There are tools available to estimate electricity use (or generation potential) of various onfarm activities, some developed for farm managers or policy makers, while others target an academic audience. An overview of these tools and models is also presented in this review.

This review seeks to compile the information from relevant studies to better quantify electricity demand of various dairy farm components across a range of global regions and management scenarios. The objective of this review is to assemble previous research on dairy farm electricity use, conservation (design/technology/management), production of renewable energy, and estimation tools. It also explores theoretical scenarios and the feasibility of net-zero-energy dairy farms, while highlighting areas for further research and information transfer.

\section{REVIEW METHODOLOGY}

Data were collected from a variety of publications, including technical reports, factsheets, modeling studies, onfarm energy audits, surveys, and sensor-based energy monitoring studies. Only the electricity component of on-farm activities was considered and, in some cases, differences observed between studies may be due to varying degrees of reliance on other forms of energy (fuel, animal power, etc.). In total, 37 studies were identified: 19 from North America, 9 from Europe, 3 from Asia, 2 from Africa, and 4 from Oceania. Study farms were classified as either "confined" (i.e., housed year-round), or "pasture-based" dairies. The term "pasture-based" can have different implications depending on region. For example, a pasture-based dairy in Canada may have their herd on pasture from May to October (Houston et al., 2014), whereas some pasture-based dairies in New Zealand graze for the entire milking season. There were 15 farms classified as confined dairies, 19 classified as pasture-based, and 13 that did not fit into either of these two broad categories or did not provide enough information. Some of these unclassified farms include open dry-lot corral systems (Bickert and Light, 1982), which are discussed separately from confined and pasture-based dairies. Electricity consumption data from each study were compiled and, when possible, partitioned by electricity use type, including milk cooling, milking system, water heating, lighting, cow comfort (ventilation fans, misting systems), manure handling, and feed handling (table 1). Electricity used for irrigation, where applicable, was also partitioned.

Confined dairy farms were sub-categorized as either freestall or tie-stall. Many free-stall barns shared the following general attributes: (1) separate feed and bedding areas with cows free to move between areas; (2) separate milking area; (3) open side- and/or end-wall design (i.e., natural ventilation); (4) more than 100 milking cows; and (5) bunker silo feed storage. The general attributes of tie-stall barns included: (1) combined feed and bedding area with the cows tethered to the stall; (2) in-stall milking; (3) mechanical ventilation; (4) over 100 milking cows; and (5) vertical silo feed storage. Overall, the comparison of free-stall and tie-stall operations in this review was done as a convenient way to group farms likely to share similar barn attributes (e.g., ventilation, milking system).

It is useful to employ energy utilization indices (EUI) to standardize electricity usage data. Since milk production per cow can vary significantly across different management and production systems, studies have noted that EUI scaled to milk $\left(\mathrm{EUI}_{\mathrm{m}}\right)$ can be a better indicator of on-farm efficiency than EUI scaled per cow (EUI $)$ (Edens et al., 2003). However, $\mathrm{EUI}_{\mathrm{c}}$ can still be useful for comparing dairy energy efficiency in cases where one wishes to isolate milk production as a separate variable. With the exception of specific cases (low input, low production systems), both types of EUI seem capable of serving as benchmarks. This study considers both electricity use per cow $\left(E U I_{c}, \mathrm{kWh} \mathrm{cow}^{-1} \mathrm{y}^{-1}\right)$ and electricity use scaled to milk production (EUI $\mathrm{m}, \mathrm{kWh} 100 \mathrm{~kg}^{-1}$ ). Descriptive statistics (mean, median, standard deviation) were calculated for multiple parameters and grouping variables using Pivot Tables in Microsoft Excel ${ }^{\circledR}$ 2016, and Tabulate 
Table 1. Breakdown of electricity consumption by dairy operation (\% of the total use). ${ }^{[a]}$

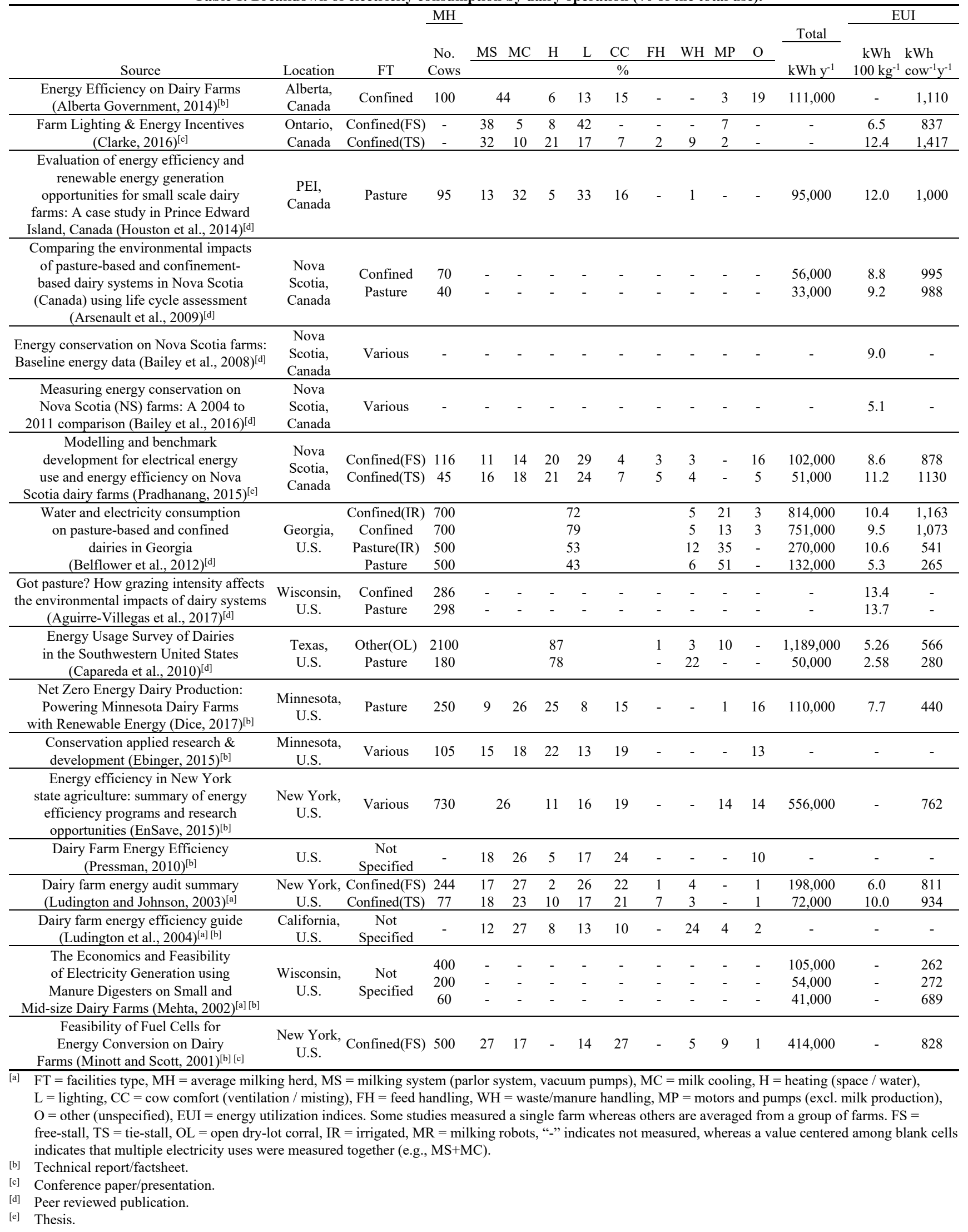




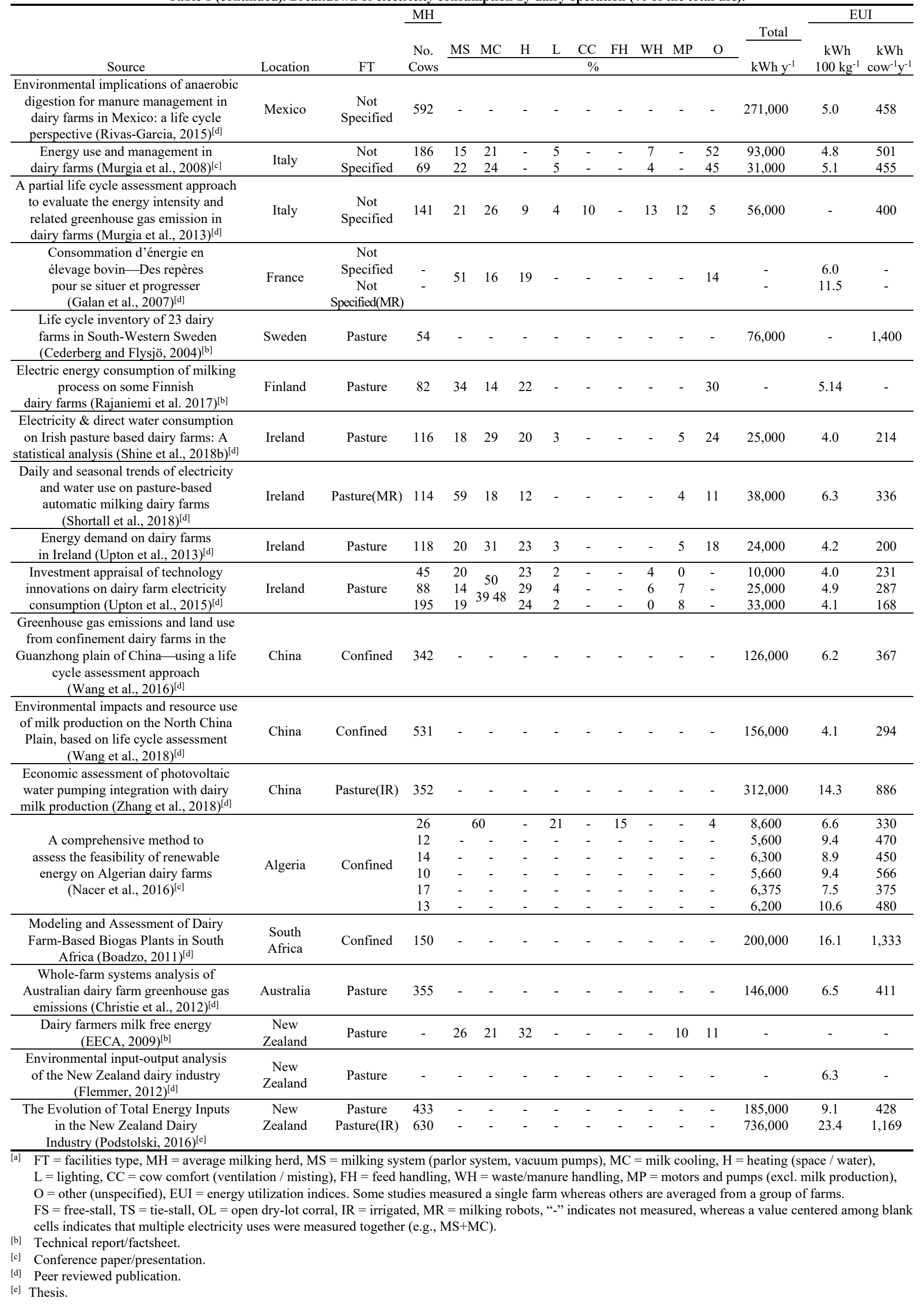


in JMP ${ }^{\circledR} 15$ (SAS Institute, Inc., Cary, N.C.). Since studies reported different parameters, the number of observations varied depending on the parameter (e.g., if a study reported number of cows but not milk production it was included in $\mathrm{EUI}_{\mathrm{c}}$ but not EUI $\mathrm{m}$ calculations). Comparisons between groups were conducted with a two sample t-test in $\operatorname{Excel}^{\mathbb{B}}$.

\section{RESULTS AND DISCUSSION \\ DAIRY ELECTRICITY CONSUMPTION}

Farms from the surveyed literature varied in size from 40 to 2100 milking cows, with an average of 307 milking cows. Milk production ranged from 11.3 to $37.1 \mathrm{~kg} \mathrm{cow}^{-1} \mathrm{~d}^{-1}$, with an average of $21.2 \mathrm{~kg} \mathrm{cow}^{-1} \mathrm{~d}^{-1}$ (median: $22.2 \mathrm{~kg} \mathrm{cow}^{-1} \mathrm{~d}^{-1}$ ) Total annual electricity usage was between 10,000 and $1,189,000 \mathrm{kWh} \mathrm{y}^{-1}$, with an average of $203,868 \mathrm{kWh} \mathrm{y}^{-1}$ (median: $103,500 \mathrm{kWh} \mathrm{y}^{-1}$ ). Electricity partitioning was available to varying degrees in some studies. Overall, the highest consuming components were the milking ( $23 \% \pm 12 \%$ s.d.), milk cooling $(22 \% \pm 9 \%)$, water and space heating $(16 \% \pm 8 \%)$, lighting $(14 \% \pm 11 \%)$, and cow comfort (fans and misting) $(15 \% \pm 7 \%)$ systems. The balance $(10 \%)$ was related to feed handling, waste handling, motors and pumps (nonmilking related), or unspecified uses. The partitioning of electricity for confined and pasture-based dairies is provided in figure 1 . The main difference in electricity use between confined and pasture-based systems is that confined systems used more electricity for cow comfort and lighting.

The $\mathrm{EUI}_{\mathrm{c}}$ and $\mathrm{EUI}_{\mathrm{m}}$ calculated from all non-irrigated

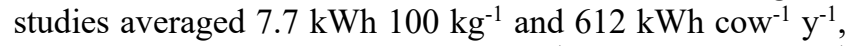

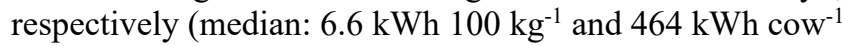
$\mathrm{y}^{-1}$; table 1 and 2). There was a wide range in the individual values, $\mathrm{EUI}_{\mathrm{m}}$ ranged from 2.6 to $23.4 \mathrm{kWh} 100 \mathrm{~kg}^{-1}$, and

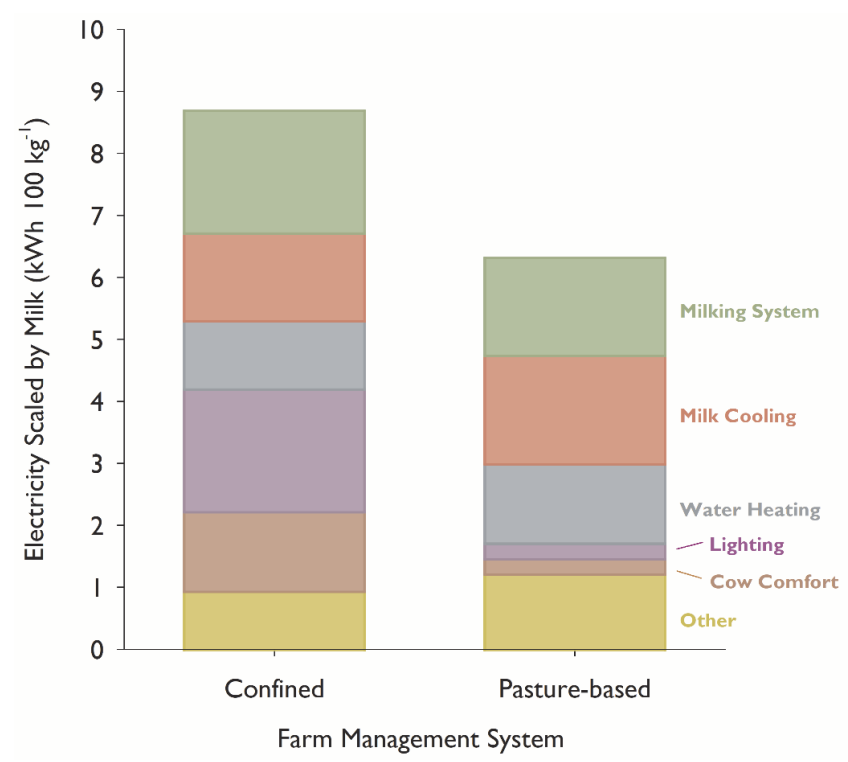

Figure 1. Representative milk-scaled electrical consumption (kWh $100 \mathrm{~kg}^{-1}$ ) breakdown by dairy operation components for confined and pasture-based dairies. Data were calculated using 4 to 8 studies from table 1 in which electricity use was partitioned into milking system, milk cooking, cow comfort (fans, misters), heating, and lighting. The balance of these components was classified as other, which includes feed handling, waste handling, other motors and pumps. Most data was from North America and Europe; irrigated studies were not included.
$\mathrm{EUI}_{\mathrm{c}}$ ranged from 168 to $1,417 \mathrm{kWh} \mathrm{cow}^{-1} \mathrm{y}^{-1}$. Part of this variability can be explained by irrigation and farm size. For 'small' non-irrigated dairies ( $\leq 100$ cows) the average EUI ${ }_{c}$ $699 \mathrm{kWh} \mathrm{cow}^{-1} \mathrm{y}^{-1}$ (median: $566 \mathrm{kWh} \mathrm{cow}^{-1} \mathrm{y}^{-1}$ ) was significantly higher than for 'medium' dairies (101-500 cows; ex-

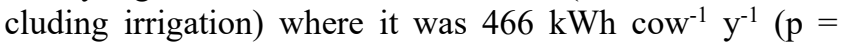
0.025 , two sample t-test; median: $\left.384 \mathrm{kWh} \mathrm{cow}^{-1} \mathrm{y}^{-1}\right)$. 'Large' dairies ( $>500$ cows; excluding irrigation) were between 'medium' and 'small' dairies, yielding an average EUI $_{\mathrm{c}}$ of $631 \mathrm{kWh} \mathrm{cow}^{-1} \mathrm{y}^{-1}$ (median: $566 \mathrm{kWh} \mathrm{cow}^{-1} \mathrm{y}^{-1}$ ).

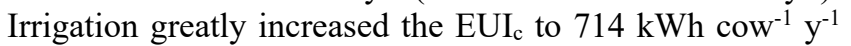
for medium, and $1166 \mathrm{kWh} \mathrm{cow}^{-1} \mathrm{y}^{-1}$ for large dairies $(\mathrm{n}=2$ for each size class). The farm size to efficiency relationship is consistent with the findings of Ebinger (2015) estimated an EUI $\mathrm{c}_{\mathrm{c}}$ of roughly 1,200 $\mathrm{kWh} \mathrm{cow}^{-1}$ for small farms (1-49 cows), and roughly $650 \mathrm{kWh} \mathrm{cow}^{-1}$ for medium farms (100499 cows). Some of these differences may be attributed to economies of scale as farm size increases, but also to a shift in the prevailing management type (confined, pasture-based) or barn design (free-stall, tie-stall) between each farm size category. Specific differences among these management types are discussed in later sections.

Average EUI $\mathrm{I}_{\mathrm{c}}$ and $\mathrm{EUI}_{\mathrm{m}}$ categorized by region (North America, Europe, Asia, Africa, Oceania) and by farm system type (confined, pasture-based) are provided in table 2. On a EUI $_{\mathrm{c}}$ basis, the region with highest EUI $\mathrm{I}_{\mathrm{c}}$ was North America $\left(762 \mathrm{kWh} \mathrm{cow}^{-1} \mathrm{y}^{-1}\right)$, followed by Oceania, Africa, Asia, and Europe ( $\left.419 \mathrm{kWh} \mathrm{cow}^{-1} \mathrm{y}^{-1}\right)$. The pattern was different on a EUI $_{\mathrm{m}}$ basis due to differences in milk production, ranging

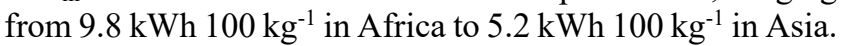
In general, pasture-based European dairies were most successful at achieving high milk yields with low electricity use. Pasture-based dairies in Oceania were similarly efficient when there was no irrigation. In contrast, North American confined systems had high milk yields but also the highest electricity demand. In general, pasture-based systems were more efficient than confined systems on a per-cow basis $\left(E I_{c}\right)$, but the difference was less pronounced when scaled to milk production $\left(\mathrm{EUI}_{\mathrm{m}}\right)$ (table 2). Irrigation increased the average $\mathrm{EUI}_{\mathrm{c}}$ by over $50 \%$ and the average $\mathrm{EUI}_{\mathrm{m}}$ by over $90 \%$.

Using $\mathrm{EUI}_{\mathrm{m}}$, the national electricity usage for milk production can be estimated from national milk production data. In Canada, for example, the dairy sector produced approximately 9.9 million tonnes of milk in 2017 (CDIC, 2018). Using the average $\mathrm{EUI}_{\mathrm{m}}$ of North American confined dairy

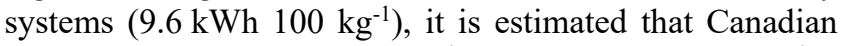
dairies use roughly $950 \mathrm{GWh} \mathrm{y}^{-1}$, or roughly $842 \mathrm{GWh} \mathrm{y}^{-1}$ if using the North American EUI $\mathrm{m}_{\mathrm{m}}$ considering all dairy sys-

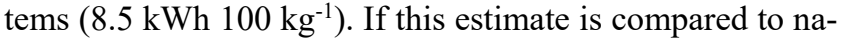
tional agriculture electricity use estimates (NRCan, 2019), the dairy industry would account for roughly $5 \%$ to $6 \%$ of total agricultural electricity use, less than has been estimated by Khakbazan (2000) using federal statistics (roughly 10\%). According to the United States Department of Agriculture, total milk production in the United States was 95.3 million tonnes in 2016 (USDA, 2017). Using the same calculation gives an estimate for on-farm direct electricity consumption of $9.15 \mathrm{TWh} \mathrm{y}^{-1}$ when using the confined $\mathrm{EUI}_{\mathrm{m}}$ and 8.10 TWh $\mathrm{y}^{-1}$ considering the EUI $\mathrm{m}_{\mathrm{m}}$ calculated from all systems. 
Table 2. Average EUI scaled per cow $\left(E U I_{c}\right)$ and by milk production (EUI $\left.I_{m}\right)$ for different general management systems (confined, pasture-based, or other/unspecified). ${ }^{\text {[a] }}$

\begin{tabular}{|c|c|c|c|c|c|c|c|c|}
\hline & \multicolumn{4}{|c|}{$\mathrm{kWh} \operatorname{cow}^{-1} \mathrm{y}^{-1}$} & \multicolumn{4}{|c|}{$\mathrm{kWh} 100 \mathrm{~kg}^{-1}$} \\
\hline & Confined & Pasture & Other & All & Confined & Pasture & Other & All \\
\hline \multicolumn{9}{|c|}{ Without Irrigation $(\mathrm{N}=42)$} \\
\hline Africa & 572 & - & - & 572 & 9.8 & - & - & 9.8 \\
\hline Asia & 331 & - & - & 331 & 5.2 & - & - & 5.2 \\
\hline Europe & - & 405 & 452 & 419 & - & 4.7 & 6.9 & 5.5 \\
\hline North America & 1,021 & 595 & 548 & 762 & 9.6 & 8.4 & 6.1 & 8.5 \\
\hline Oceania & - & 420 & - & - & - & 7.3 & - & 7.3 \\
\hline Average & 769 & 475 & 519 & 612 & 9.2 & 6.6 & 6.6 & 7.7 \\
\hline Median & 824 & 312 & 480 & 464 & 9.2 & 5.8 & 5.2 & 6.6 \\
\hline \multicolumn{9}{|l|}{ With Irrigation $(\mathrm{N}=4)$} \\
\hline Average & 1,163 & 865 & - & 940 & 10.4 & 16.1 & - & 14.7 \\
\hline Median & 1,163 & 886 & - & 1,025 & 10.4 & 14.3 & - & 12.5 \\
\hline
\end{tabular}

Data from non-irrigated systems are partitioned by region, whereas data from irrigated systems are aggregated. Average and median values are shown for each management type (column) within each irrigation group. Data in this table were generated using components of the data presented in table 1.

Global dairy production was estimated at 852 million tonnes (FAO, 2020), with most milk being produced in Asia, Europe, and North America (table 3). A range of electricity estimates were calculated for each region depending on the EUI used. The actual value would depend on the distribution of farming systems within each region. Overall, the total electricity use estimates range from 55 to $77 \mathrm{TWh} \mathrm{y}^{-1}$, excluding irrigation. Using the average $\mathrm{EUI}_{\mathrm{m}}$ would give a global value of 64.2 $\mathrm{TWh} \mathrm{y}^{-1}$.

Whether scaled per cow or per unit of production, the annual dairy electricity consumption varied substantially among the studies surveyed. Ludington et al. (2004) pointed to three main factors that contribute to this variability: total milk production, milk production efficiency, and electricity conservation technology. The next sections examine variability stemming from two broad, sometimes overlapping areas: (i) farm design and management, and (ii) technology and equipment.

\section{Farm Design and Management}

The choice of farm design is a product of multiple interacting factors including the regional climate, landscape, availability of labor, access to capital, market factors, and preference. Climate enables year-round pasturing in warm regions with adequate rainfall and land. Regions with freezing winters require barns with appropriate ventilation to manage temperature, humidity, feed delivery, cow cleanliness, milking, bedding, and manure management (Bickert and Light,

Table 3. Global milk production and estimated electricity usage (2019 data from FAO, 2020). ${ }^{[\mathrm{a}]}$

\begin{tabular}{|c|c|c|c|c|}
\hline \multirow[b]{2}{*}{ Region } & \multirow[b]{2}{*}{$\begin{array}{c}\text { Milk } \\
\left(\text { million } \mathrm{t} \mathrm{y}^{-1}\right)\end{array}$} & \multicolumn{3}{|c|}{ Total Electricity Estimate } \\
\hline & & $\begin{array}{c}\text { Regional } \\
\text { EUI }_{\mathrm{m}} \\
\left(\mathrm{TWh} \mathrm{y}^{-1}\right) \\
\end{array}$ & $\begin{array}{c}\text { Confined } \\
\text { EUI }_{\mathrm{m}} \\
\left(\mathrm{TWh} \mathrm{y}^{-1}\right) \\
\end{array}$ & $\begin{array}{c}\text { Pasture } \\
\text { EUI }_{\mathrm{m}} \\
(\mathrm{TWh} / \mathrm{y}) \\
\end{array}$ \\
\hline Africa & 46.8 & 4.6 & 4.3 & 3.1 \\
\hline Asia & 360 & 18.7 & 33.1 & 23.8 \\
\hline Europe & 226 & 12.4 & 20.8 & 14.9 \\
\hline North America & 108.6 & 9.2 & 10.0 & 7.2 \\
\hline South America & 61.8 & - & 5.7 & 4.1 \\
\hline Central America & 18.2 & - & 1.7 & 1.2 \\
\hline Oceania & 30.7 & 2.2 & 2.8 & 2.0 \\
\hline Global & 852 & - & 76.7 & 55.0 \\
\hline $\begin{array}{l}\text { Electricity de } \\
\text { each region } \\
\text { Confined and } \\
\text { respectively) }\end{array}$ & $\begin{array}{l}\text { land is estimate } \\
\text { here available) } \\
\text { Pasture system }\end{array}$ & $\begin{array}{l}\text { using the } \\
\text { ad the ove } \\
9.2 \text { and } 6 .\end{array}$ & $\begin{array}{l}\text { m data fro } \\
\text { average E } \\
\text { Vh } 100 \mathrm{~kg}\end{array}$ & $\begin{array}{l}\text { ble } 2 \text { for } \\
\text { for }\end{array}$ \\
\hline
\end{tabular}

1982). Barn design and milking system affect the labor requirements, with free-stall barns requiring less labor and tiestall barns generally needing more labor but may be preferred for smaller or registered herds. Warm, dry, regions are more suitable for open dry-lot corral systems where cows are fed outdoors and provided with shade (Bickert and Light, 1982). This lowers the cost of construction and ventilation compared to barn-based housing. Market factors such as the cost and availability of concentrates, the ability to sell milk seasonally (e.g., pasture with seasonal calving) versus the requirement for consistent milk production throughout the year are also important factors affecting how farms are managed.

In terms of electricity use, the average $\mathrm{EUI}_{\mathrm{m}}$ and $\mathrm{EUI}_{\mathrm{c}}$ of

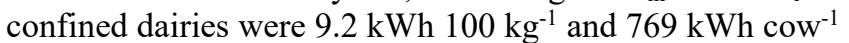

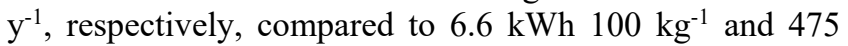
$\mathrm{kWh} \operatorname{cow}^{-1} \mathrm{y}^{-1}$ for pasture-based dairies (excluding irrigation). Pasture-based dairies were generally more energy-efficient on a per cow basis $\left(\mathrm{EUI}_{\mathrm{c}}\right)$ due to fewer electricity consuming activities (e.g., lights, fans, pumps, etc.). However, pasture-based operations generally exhibited lower milk yields per cow than confined dairies. Cases where there was a large difference in per cow milk production between these two systems may be related to seasonal milking in the pasture-based dairies, but this information could not be confirmed in the studies that directly compare the two. In a North American study, Belflower et al. (2012) reported that a confined dairy had more than twice the per cow milk production of a pasture-based dairy (roughly $11,000 \mathrm{~kg} \mathrm{cow}^{-1} \mathrm{y}^{-}$ ${ }^{1}$ vs. roughly $5,000 \mathrm{~kg} \mathrm{cow}^{-1} \mathrm{y}^{-1}$ ). As described by Delaby et al. (2020), the high genetic potential for milk production of Holstein cows are unable to meet their potential in a grazing system without feed supplementation. This lower production rate is also observed in African and New Zealand dairies, many of which adopt a lower-input, lower-production farming strategy (Nacer et al., 2016; Podstolski, 2016).

The electricity consumption of fans (cow comfort) and lighting has been noted as a data gap (Dyer and Desjardins, 2006). In addition, the electricity needed to handle feed and manure is often not reported or is combined with other components. Fans and misting systems (i.e., cow comfort) are major contributors to the overall electricity budget on confined dairies, representing $140 \mathrm{kWh} \mathrm{cow}^{-1} \mathrm{y}^{-1}$, on average (roughly $15 \%$ of the total budget). As expected, cow comfort-related electricity demand is less significant for pasturebased systems, where it is estimated at $21 \mathrm{kWh} \mathrm{cow}^{-1} \mathrm{y}^{-1}(4 \%$ 
of the total budget). Lighting is important on confined dairies, where it accounts for $23 \%$ of electricity use $(218 \mathrm{kWh}$ cow $\left.^{-1} \mathrm{y}^{-1}\right)$, compared to $4 \%$ on pasture-based dairies $\left(21.0 \mathrm{kWh} \mathrm{cow}^{-1} \mathrm{y}^{-1}\right)$, when it was reported at all (roughly half of the time). Feed handling $\left(3.6 \%, 34 \mathrm{kWh} \mathrm{cow}^{-1} \mathrm{y}^{-1}\right)$ and manure handling $\left(4.8 \%, 45 \mathrm{kWh} \mathrm{cow}^{-1} \mathrm{y}^{-1}\right)$ made contributions to the confined dairy electricity budget, but were mostly absent for pasture-based dairies. Taken together, the lower electricity use for lighting and cow comfort were the main drivers of lower EUI in pasture-based dairies (fig. 1). Open dry-lot corral systems are expected to have lighting requirements more akin to those of pasture-based dairies. For example, Capareda et al. (2010) calculated that lighting accounted for $3 \%$ of the electricity demand on an open dry-lot corral system.

The average $\mathrm{EUI}_{\mathrm{c}}$ in irrigated systems was $>50 \%$ higher than non-irrigated systems, and the $\mathrm{EUI}_{\mathrm{m}}$ was almost twice as high (table 2). Studies that include irrigation in their electricity budgets noted that irrigation can account for up to $50 \%$ of the total electricity usage (Belflower et al., 2012; Podstolski, 2016). The electricity used by irrigation is estimated to range from 200 to $275 \mathrm{kWh} \mathrm{ML}^{-1}$ of water, depending on the type of irrigation used (Christie et al., 2012). Most studies that reported irrigation as an important electricity factor were pasture-based dairies. Including irrigation significantly increased the overall electricity usage and $\mathrm{EUI}_{\mathrm{m}}$ of pasture-based dairies, which in one example rose from 5.3 to

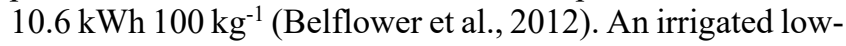
input, low-production pasture system in New Zealand had the highest $\mathrm{EUI}_{\mathrm{m}}\left(23.4 \mathrm{kWh} 100 \mathrm{~kg}^{-1}\right)$ and a moderately high $\mathrm{EUI}_{\mathrm{c}}\left(1,169 \mathrm{kWh} \mathrm{cow}^{-1} \mathrm{y}^{-1}\right)$ (Podstolski, 2016). The high electricity usage of this type of farm management makes it more vulnerable to fluctuations in weather and the price of electricity. For example, Wells (2001) found that the New Zealand drought conditions in 1998-1999 resulted in increased irrigation, which in turn increased electricity use by $15 \%$ to $20 \%$ compared to $1996-1997$. Of course, irrigation is not associated only with pasture-based production systems; all dairy feed crops can be irrigated, depending on the production region. However, given the higher overall electricity budget of confined dairies, irrigation, when it occurs, tends to be a lower fraction of the budget. For example, Belflower et al. (2012) noted that irrigation on a confined dairy accounted for $63,000 \mathrm{kWh} \mathrm{y}^{-1}$, or $8.4 \%$ of total electricity use.

Combined, the milking and milk-cooling systems are responsible for an average of $370 \mathrm{kWh} \mathrm{cow}^{-1} \mathrm{y}^{-1}$ on confined dairies and an average of $286 \mathrm{kWh} \mathrm{cow}^{-1} \mathrm{y}^{-1}$ on pasturebased dairies. In parlor-based milking systems, milking times are usually marked by surges in electricity demand of 6 to 8 times the base load (Mehta, 2002; Upton et al., 2013). On farms equipped with milking robots, the overall electricity usage consisted of the energy needs for the milking system and air compressors that use electricity consistently throughout the day (Calcante et al., 2016; Shortall et al., 2018). Calcante et al. (2016) reported that the average daily electricity use of five different automated milking systems was $64 \mathrm{kWh} \mathrm{d}^{-1}$ (roughly 34 for the milking unit plus 30 for

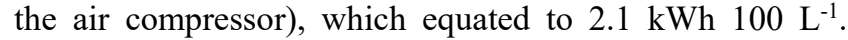
Shortall et al. (2018) reported an average of $111 \mathrm{kWh} \mathrm{cow}^{-1}$ $\mathrm{y}^{-1}$ for the milking system and $87 \mathrm{kWh} \mathrm{cow}^{-1} \mathrm{y}^{-1}$ for the air compressor, which accounted for $59 \%$ of the total electricity usage on the pasture-based farms. The number of milkings per day will affect the total electricity demand and $E I_{c}$ of a dairy operation, although the $\mathrm{EUI}_{\mathrm{m}}$ will change less due to increased milk production per cow resulting from an extra milking (11 to 19\% increase; Allen et al., 1986). Shortall et al. (2018) also showed this to be the case on farms with milking robots, where the number of milking times and electricity usage were positively correlated.

On average, free-stall operations were more energy-efficient than tie-stall operations. In the three reports that compared the two systems, the EUI $\mathrm{m}_{\mathrm{m}}$ and $\mathrm{EUI}_{\mathrm{c}}$ were $7.0 \mathrm{kWh}$ $100 \mathrm{~kg}^{-1}$ and $842 \mathrm{kWh} \mathrm{cow}^{-1} \mathrm{y}^{-1}$ for free-stalls compared to

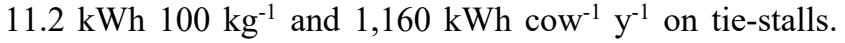
These differences may reflect the natural ventilation in freestall barns as well as the economies of scale and the newer, more efficient technologies of the free-stall facilities, which were larger (180 milking cows) and had newer barn designs than the tie-stall facilities (61 milking cows). Feed handling electricity use was lower in free-stall operations $(18 \mathrm{kWh}$ $\left.\mathrm{cow}^{-1}\right)$ than in tie-stall operations $\left(51 \mathrm{kWh} \mathrm{cow}^{-1}\right)$. This is likely because free-stall operations use more diesel-powered feed delivery due to the use of bunker silos (more economical for larger dairies; OMAFRA, 2011), whereas tie-stall operations often use electric feed delivery from vertical silos. The same may be true for waste handling equipment, which is typically diesel-powered in free-stall operations compared to electric in tie-stall operations, resulting in electricity demands of 37 and $58 \mathrm{kWh} \mathrm{cow}^{-1}$, respectively.

\section{Technology and Equipment}

Technology can have an impact, both positive and negative, on the electricity requirement of dairy farms. This section examines the literature on the electricity usage of various types of equipment and related conservation technologies. The dairy industry in many countries is transitioning from predominantly pasture-based systems to predominantly confined systems (Meul et al., 2012). It has been stated that electricity use on dairy operations had increased in step with the proportion of cows confined and with increases mechanization over many decades (Kraatz, 2012).

Potential energy-efficient technologies identified include variable speed drives (VSD), efficient lighting (Ebinger, 2015), efficient ventilation, pre-cooling heat exchangers, scroll compressors (Pressman, 2010), and refrigeration heat recovery (RHR) systems (Brinker et al., 2013; Alberta Government, 2014). As the name suggests, VSD systems adjust motor speed to match demand and optimize performance (e.g., pumps, compressors, fans). RHR systems function by connecting refrigeration heat exchangers to a water tank and using the discharge heat to partially temper the water before it is heated to the required temperature (FarmEnergy Nova Scotia, 2017). Scroll compressors use two spirals (or scrolls), one fixed and the other not, to create positive pressure more efficiently than a piston (Grace et al., 2002). These and a number of other technologies for reducing electricity consumption (see summary in table 4) can provide energy savings of $20 \%$ to $60 \%$ for the given component. 
Table 4. Dairy electricity conservation strategies and potential savings. ${ }^{[a]}$

\begin{tabular}{|c|c|c|c|c|c|}
\hline Reference & Location & $\mathrm{MH}$ & Farm Type & Strategy & $\begin{array}{l}\text { Energy Saving } \\
\text { For Component }\end{array}$ \\
\hline \multirow{4}{*}{$\begin{array}{l}\text { Energy Efficiency on Dairy Farms } \\
\quad(\text { Alberta Government, 2014) }\end{array}$} & \multirow{4}{*}{$\begin{array}{l}\text { Alberta, } \\
\text { Canada }\end{array}$} & \multirow{4}{*}{-} & \multirow{4}{*}{ Not Specified } & $\begin{array}{l}\text { Energy saving on the life of the } \\
\text { vacuum pump by using a VSD }\end{array}$ & $60 \%$ \\
\hline & & & & $\begin{array}{c}\text { Replacement an oversized } \\
\text { pump with a VSD }\end{array}$ & $80 \%$ \\
\hline & & & & Refrigeration heat recovery & $20 \%-50 \%$ \\
\hline & & & & $\begin{array}{l}\text { Replacement of traditional water heater } \\
\text { with tank less (on demand) heater }\end{array}$ & $60 \%$ \\
\hline \multirow{2}{*}{$\begin{array}{l}\text { Dairy Farm Retro-commissioning: } \\
\text { Retrofit Study of HVLS and } \\
\text { Tunnel Ventilated Barns. } \\
\text { (Brinker et al., 2013) }\end{array}$} & \multirow{2}{*}{$\begin{array}{l}\text { Wisconsin, } \\
\text { U.S. }\end{array}$} & \multirow{2}{*}{192} & \multirow{2}{*}{ Confined - FS } & $\begin{array}{l}\text { Installation of VSD and staged } \\
\text { controls with tunnel ventilation } \\
\text { systems (cold climate) }\end{array}$ & $34 \%$ \\
\hline & & & & $\begin{array}{l}\text { Installation of VSD and staged } \\
\text { controls with tunnel ventilation } \\
\text { systems (warmer climate) }\end{array}$ & $5 \%$ \\
\hline $\begin{array}{l}\text { Energy Efficient Technology } \\
\text { Selection for Dairy Farms: Milking } \\
\text { Cooling and Electric Water Heating } \\
\text { (Corscadden et al., 2014) }^{[\mathrm{d}]} \\
\end{array}$ & $\begin{array}{l}\text { Nova } \\
\text { Scotia, } \\
\text { Canada }\end{array}$ & $17-380$ & $\begin{array}{l}\text { Confined - } \\
\text { FS/TS }\end{array}$ & $\begin{array}{l}\text { Water heating for smaller farms } \\
\text { A combination of water heating } \\
\text { and pre-cooling heat exchangers } \\
\text { for larger farms. }\end{array}$ & - \\
\hline \multirow{2}{*}{$\begin{array}{l}\text { Energy savings achieved from } \\
\text { heat recovery systems (Kammel } \\
\text { and Patoch, 1993) }\end{array}$} & \multirow{2}{*}{$\begin{array}{l}\text { Wisconsin, } \\
\text { U.S. }\end{array}$} & \multirow{2}{*}{$32-120$} & \multirow{2}{*}{ Various } & $\begin{array}{l}\text { Heat recovery system recaptured } \\
\text { on heating water }\end{array}$ & $48 \%$ \\
\hline & & & & $\begin{array}{l}\text { Heat recovery system recaptured } \\
\text { on cooling milk }\end{array}$ & $7 \%$ \\
\hline $\begin{array}{l}\text { Energy use and management in } \\
\text { dairy farms (Murgia et al., 2008) }\end{array}$ & $\begin{array}{l}\text { Sassari, } \\
\text { Italy }\end{array}$ & $40-300$ & Confined & Installing a VSD & $50 \%$ \\
\hline $\begin{array}{c}\text { Rapid milk cooling control } \\
\text { with varying water and energy } \\
\text { consumption (Murphy et al., 2013) } \\
\text { [d] }\end{array}$ & $\begin{array}{l}\text { Cork, } \\
\text { Ireland }\end{array}$ & & Pasture & Optimizing water rates & $34 \%$ \\
\hline \multirow{2}{*}{ 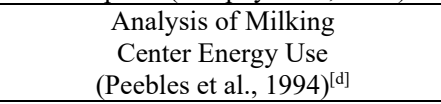 } & \multirow{2}{*}{$\begin{array}{l}\text { Wisconsin, } \\
\text { U.S. }\end{array}$} & \multirow{2}{*}{$60-400$} & \multirow[b]{2}{*}{ Confined } & Heat recovery system & $42 \%-48 \%$ \\
\hline & & & & Pre-cool heat exchanger & $38 \%-46 \%$ \\
\hline \multirow{2}{*}{$\begin{array}{l}\text { Electric energy consumption } \\
\text { of milking process on some Finnish } \\
\text { dairy farms (Rajaniemi et al., 2017) }\end{array}$} & \multirow{2}{*}{$\begin{array}{l}\text { Helsinki, } \\
\text { Finland }\end{array}$} & \multirow{2}{*}{$72-91$} & \multirow[b]{2}{*}{ Confined - FS } & $\begin{array}{l}\text { Placing the condenser of the } \\
\text { refrigeration system outside }\end{array}$ & $30 \%$ \\
\hline & & & & $\begin{array}{l}\text { Installing milk pre-coolers } \\
\text { and a heat recovery system } \\
\text { from the milk cooling process }\end{array}$ & $25 \%$ \\
\hline $\begin{array}{l}\text { Electricity \& direct water } \\
\text { consumption on Irish pasture } \\
\text { based dairy farms: A statistical } \\
\text { analysis (Shine et al., 2018b) }\end{array}$ & $\begin{array}{l}\text { Muster, } \\
\text { Ireland }\end{array}$ & 116 & Pasture & Pre-cooling milk with ground water & $21 \%$ \\
\hline $\begin{array}{l}\text { Strategies to reduce energy } \\
\text { use in dairy milking facilities } \\
\text { (Upton et al., 2014b) }\end{array}$ & $\begin{array}{l}\text { Munster, } \\
\text { Ireland }\end{array}$ & $45-195$ & Pasture & $\begin{array}{l}\text { Ice bank milk cooling systems, kWh } \\
\text { Savings cost savings (peak-load shifting) } \\
\text { Solar thermal water heating, } \mathrm{kWh} \text { savings }\end{array}$ & $\begin{array}{c}21 \%-26 \% \\
38 \%-46 \% \\
8 \%-18 \%\end{array}$ \\
\hline $\begin{array}{l}\text { [a] } \mathrm{MH}=\text { herd size (milking cows), FS } \\
\text { [b] Technical report/factsheet. } \\
\text { [c] Conference paper/presentation. } \\
\text { [d] Peer reviewed publication. }\end{array}$ & tall, $\mathrm{T}$ & $\overline{11,}$ & $\overline{\text { riabl }}$ & rive, $\mathrm{LED}=$ light emitting diode. & \\
\hline
\end{tabular}

The effect of combining multiple technologies using theoretical scenarios is shown in table 5, illustrating how multiple conservation technologies reduce annual electricity consumption. For example, on a 250-cow confined North American dairy farm, adding conservation technology to the milking, milk cooling, water heating, and lighting systems can result in savings of between $11,200 \mathrm{kWh} \mathrm{y}^{-1}$ and $19,200 \mathrm{kWh} \mathrm{y}^{-1}$ for each system, for a total combined savings of roughly $76,500 \mathrm{kWh} \mathrm{y}^{-1}$, a $30 \%$ reduction. At the same time, the EUI $\mathrm{I}_{\mathrm{c}}$ can potentially decrease to $715 \mathrm{kWh}$ $\operatorname{cow}^{-1} \mathrm{y}^{-1}$. Similar proportional savings are realized, overall, in pasture-based systems, despite lower initial electricity use (table 5). Interdependence between different types of conservation technologies may have an effect on the theoretical savings presented, but for the sake of simplicity, this potential interaction has not been considered in the analysis.

Table 5. Theoretical electricity use scenarios for a 250 milking cow dairy farm with contrasting management systems. ${ }^{[a]}$ Farm

\begin{tabular}{|c|c|c|c|c|c|c|c|c|c|c|c|c|}
\hline \multicolumn{2}{|c|}{$\begin{array}{c}\text { Farm } \\
\text { Characteristics }\end{array}$} & \multicolumn{2}{|c|}{ Before } & \multicolumn{5}{|c|}{ Theoretical Savings } & \multicolumn{2}{|c|}{ After } & \multicolumn{2}{|c|}{$\begin{array}{c}\text { Total } \\
\text { Savings }\end{array}$} \\
\hline & Milking & $\mathrm{kWh}$ & & MS & $\mathrm{MC}$ & $\mathrm{H}$ & $\mathrm{L}$ & $\mathrm{CC}$ & & $\mathrm{kWh}$ & $\mathrm{kWh}$ & \\
\hline System & Cows & $\operatorname{cow}^{-1} \mathrm{y}^{-1}$ & $\mathrm{kWh} \mathrm{y}^{-1}$ & & & $\mathrm{kWh} \mathrm{y}^{-1}$ & & & $\mathrm{kWh} \mathrm{y}^{-1}$ & $\operatorname{cow}^{-1} y^{-1}$ & $\operatorname{cow}^{-1} y^{-1}$ & $\%$ \\
\hline Confined & 250 & 1021 & 255,250 & 11,494 & 17,272 & 19,159 & 17,336 & 11,212 & 178,777 & 715 & 306 & $30 \%$ \\
\hline Pasture-based & 250 & 405 & 101,250 & 5,323 & 13,249 & 13,249 & 709 & 0 & 68,691 & 275 & 130 & $32 \%$ \\
\hline
\end{tabular}




\section{Milking and Milk-Cooling Systems}

Milking and milk cooling systems are major components of electricity consumption on dairy farms, accounting, on average, for approximately $40 \%$ to $50 \%$ of a dairy's electricity budget (fig. 1). A pre-cooling heat exchanger can reduce milk temperature before it enters the bulk tank by up to $26^{\circ} \mathrm{C}$ (to within $4^{\circ} \mathrm{C}$ of the water temperature; Rajaniemi et al., 2017), which in turn reduces the electricity required for refrigeration by roughly $25 \%$ to $60 \%$ (Sanford, 2003b; table 4). In the best case scenario, on a confined dairy operation, this could translate into a savings of up to $91 \mathrm{kWh}$ $\operatorname{cow}^{-1} \mathrm{y}^{-1}$, or roughly $10 \%$ of the budget. Placing the refrigeration condenser outdoors is an option in cold climates, and doing so can reduce cooling-related electricity consumption by up to $30 \%$, which, by our estimates is equivalent to roughly $45 \mathrm{kWh} \mathrm{cow}^{-1} \mathrm{y}^{-1}$ (Rajaniemi et al., 2017; table 4). In addition, replacing a reciprocating compressor with a scroll compressor as the driver of the pre-cooling heat exchangers can reduce milk cooling electricity demand by $20 \%$ (Ludington et al., 2004). Ebinger (2015) illustrated a case where doing so led to a savings of roughly $26.5 \mathrm{kWh} \mathrm{cow}^{-1}$ $\mathrm{y}^{-1}$. Applying the $20 \%$ savings suggested by Ludington et al. (2004) to the EUI ${ }_{c}$ of confined dairies $\left(769 \mathrm{kWh} \mathrm{cow}^{-1} \mathrm{y}^{-1}\right.$ total; $125 \mathrm{kWh} \mathrm{cow}^{-1} \mathrm{y}^{-1}$ for milk cooling) gives a savings of close to $25 \mathrm{kWh}^{-1} \operatorname{cow}^{-1} \mathrm{y}^{-1}$. In addition to this technology, it has been reported that if the milking system vacuum pump is fitted with a VSD, electricity use reductions of $60 \%$ to $80 \%$ are observed for that component (Alberta Government, 2014; Dice, 2017; table 4). Ebinger (2015) found this to be equivalent to roughly $60 \mathrm{kWh} \mathrm{cow}^{-1} \mathrm{y}^{-1}$. Assuming a reduction of $70 \%$ and using the partitioning of $\mathrm{EUI}_{\mathrm{c}}$ for confined dairies, one can expect savings of as much as ca. $100 \mathrm{kWh}$ $\operatorname{cow}^{-1} \mathrm{y}^{-1}$. Another application of VSD is to optimize milk flow rate through the pre-cooling heat exchanger to improve heat transfer, which can increase efficiency by another $30 \%$ (Murphy et al., 2013; Alberta Government, 2014; table 4).

\section{Water and Space Heating}

Hot water is used for cleaning equipment (i.e., pipeline) after each milking, as well as for cleaning the bulk tank. On average, water heating and, to a lesser extent, space heating account for roughly $16 \%$ of a dairy's total electricity budget (ranging from $2 \%$ to $32 \%$ ). Here again, energy can be conserved by using recovered heat (from RHR units) to preheat water. It is estimated that $20 \%$ to $50 \%$ of the waste heat energy from the milk refrigeration system can be captured (Alberta Government, 2014; table 4). Ebinger (2015) found that RHR was capable of conserving roughly $8,000 \mathrm{kWh} \mathrm{y}^{-1}$ on dairies averaging 75 cows. Beard (2012) estimated that insulating water heater tanks can reduce the electricity demand of that component by $4 \%$ to $9 \%$. Alternatively, tankless (i.e., on-demand) water heaters can be used, which require less electricity than conventional heaters (Alberta Government, 2014). House et al. (2014) noted that cleaning protocols used on milking equipment can vary greatly from farm to farm. Variation in the amount of hot water used as a result of different wash protocols would affect total electricity demand. The cleaning of pipelines and bulk tanks has traditionally been done with hot water, but low temperature detergents have recently been approved for use in the dairy industry
(DFC, 2017) and are commercially available. For example, a chlorinated alkaline detergent is available from De Laval (Kansas City, Mo.) and according to the manufacturer it uses dispersants and hydrotopes to clean at a reduced temperature. Although not widely adopted, such detergents and cleaning practices can reduce the need for hot water and have been shown to be effective in a case-study (Gentilini and Lopez-Benavides, 2014).

\section{Lighting}

Electricity use for lighting in confined dairies accounts for between $13 \%$ and $42 \%$ of total electricity use, for an average of $23 \%$. The observed variability is likely due to the type of lighting used and to factors such as barn design, natural light, and stocking density. Clarke and House (2006) estimated that a roughly $75 \%$ reduction in electricity use can be achieved by switching from incandescent to T8 fluorescent lighting. Numerous studies have demonstrated the advantages of LED lighting over other lighting sources. LED lighting can deliver higher output while reducing electricity consumption by up to $90 \%$ compared to incandescent bulbs (Clarke and House, 2006; Ebinger, 2015; EnSave, 2015). This would correspond to a decrease of up to $197 \mathrm{kWh}$ $\operatorname{cow}^{-1} \mathrm{y}^{-1}$ for $\mathrm{EUI}_{\mathrm{c}}$ in confined dairies. By applying this theoretical savings to one of the least lighting-efficient studies presented in table 1 (244 cows, $\left.198,000 \mathrm{kWh} \mathrm{y}^{-1}\right)$, a reduction of roughly $46,000 \mathrm{kWh} \mathrm{y}^{-1}$ could be achieved $(23 \%$ of the annual usage). Lighting-related savings are likely to be most impactful in confined dairies, especially those that employ "long-day lighting" management strategies to reduce seasonal fluctuations in milk production (Ludington et al., 2004). Due to a natural physiological response, increasing light exposure from 12 to 16 or $18 \mathrm{~h} \mathrm{~d}^{-1}$ increases milk production by $2.5 \mathrm{~kg} \mathrm{cow}^{-1} \mathrm{~d}^{-1}$ on average (Dahl et al. 2000). Gould and Go (2015) found that increasing the photoperiod with LED lighting improved milk yield by $8 \%$ and expected to reduce electricity cost by half compared to metal halide lighting. Besides the lighting type, the design of lighting and windows can not only lower electricity usage, but also increase milk production (Clarke and House, 2006). Natural lighting, which is more prevalent in more modern barn design (i.e., curtain walls) and farm management strategies (i.e., free-stall), can help reduce lighting requirements of dairy buildings.

\section{Cow Comfort}

Heat stress negatively affects dairy cows, which in turn can reduce milk production (Bernabucci et al., 2014). To maintain good air quality and to keep cows cool during warm weather, barns are ventilated using either passive (e.g., natural air movement through curtain walls) or mechanical strategies (e.g., tunnel or cross-flow ventilation). Both designs use fans and may have additional water-based cooling using misters or sprinklers. These cow comfort components account for $15 \%$ of the total electricity use on confined dairies (table 1). Passive ventilation uses little electricity (e.g., to control curtains) so it is best from an electricity conservation point of view. However, natural ventilation is not ideal in every location or climate, and supplemental fans in the barn are usually still required. 
Where air circulation is needed, high-volume, low-speed (HVLS) fans are more energy-efficient than smaller lowvolume high-speed (LVHS) fans, achieving the same circulation rate using roughly $85 \%$ less electricity. Applying this to the EUI $\mathrm{C}_{\mathrm{c}}$ of confined dairies, this could translate to a reduction of over $100 \mathrm{kWh} \mathrm{cow}^{-1} \mathrm{y}^{-1}$ if HVLS were not already implemented in the barn. HVLS fans are best suited to freestall barns with high ceilings and open sides (Sanford, 2003a). LVHS fans blowing air over the cows may be more effective at cooling the cows. Increasing the size of LVHS fans can improve energy efficiency. By switching from 24 in. fans to fans measuring $50 \mathrm{in}$. or larger, a $43 \%$ increase in efficiency per fan can be achieved (from $0.008 \mathrm{~m}^{3} \mathrm{~s}^{-1} \mathrm{~W}^{-1}$ to $0.011 \mathrm{~m}^{3} \mathrm{~s}^{-1} \mathrm{~W}^{-1}$; Sandford, 2003a). Fans can be equipped with VSDs, which use environmental parameters to optimize the ventilation rate in real-time (Sanford, 2003a). Smart controls can be used to optimize ventilation by adjusting the fan speed (variable or multi-stage) or on-off cycles according to barn temperature. For example, in cold climates, efficient ventilation with automated control systems can reduce the electricity demand of fans by as much as $34 \%$ compared to manually controlled fans (table 4; Brinker et al., 2013). Although the potential savings are unquantified, in barns equipped with LVHS fans, cows can be cooled more efficiently by adding water sprinkling to fans (Sanford, 2003a). Therefore, electricity savings could be achieved through water-based cow cooling, depending on the electricity demand of the water delivery system, especially in barns where HVLS ventilation is not possible.

\section{Milking Robots (Automated Milking Systems)}

Milking robots are an alternative to in-stall milking or milking parlors. The electricity implications of milking robots can be observed by looking at two pasture-based studies with similar sized farms: one focused on farms with milking robots (114 cow average, Shortall et al., 2017) and one focused on farms with parlors (118 cow average, Upton et al., 2013). On average, the overall electricity usage for the farms with milking parlors was nearly half that of farms with milking robots (24,000 and 38,000 $\mathrm{kWh} \mathrm{y}^{-1}$, respectively) which is consistent with the annual electricity use for milking parlors $(4,800 \mathrm{kWh}$ $\mathrm{y}^{-1}$ ) being considerably less than milking robots (roughly $12,500 \mathrm{kWh}^{-1}$ ). Similarly, the review by Örs and Oğuz (2018) indicated 39\% higher electricity consumption with robotic milking systems compared to conventional milking parlors. This is likely due to the fact that milking robots are always "on" (i.e., standby), even when not in operation, and therefore are always consuming electricity.

\section{Electricity Monitoring}

Electricity monitoring systems have been developed to inform users of energy use patterns. Although studies have not been conducted within a dairy context specifically, research on households have shown the potential of feedback in supporting changes in electricity use through behavior change (Stinson, 2015). Some electricity providers provide high-resolution consumption data which enable dairy farms to monitor or react in real time to changes in total electricity consumption. Electricity metering and submetering can be used to track patterns of overall electricity use and use at the component and equipment level. This approach is often used in industrial settings, but is less common in agriculture (Hinck, 2018). Monitoring can be used with a maintenance program to detect equipment problems before they lead to electricity waste. A pilot study of real-time electricity consumption tracking on farms in Minnesota has begun to use this approach to analyze and improve the energy efficiency of dairy barns (Hinck, 2018). In The United States and Canada, smart meters have been recently introduced on farms in some regions.

\section{Generating Electricity}

One option for on-farm electricity generation is anaerobic digestion. This process uses manure and other organic wastes to produce biogas (a mixture of methane and other gases), which in turn can be used to generate electricity as well as a significant amount of process heat (from the generator). Biogas typically has an energy content of 22 to $27 \mathrm{MJ} \mathrm{m}^{-3}$ (6.1 to $7.5 \mathrm{kWh} \mathrm{m}^{-3}$ ) (Biogas Association, 2013). On average, a biodigester has the capacity to produce at least $3 \mathrm{kWh} \mathrm{cow}^{-1} \mathrm{~d}^{-1}$ (roughly $1095 \mathrm{kWh} \mathrm{cow}^{-1} \mathrm{y}^{-1}$ ), or 2 to 3 times more if high energy co-feedstocks are co-digested with the manure (El-Mashad and Zhang, 2006; Yiridoe et al., 2009; OMAFRA, 2016; Purdy et al., 2018). Since the aver-

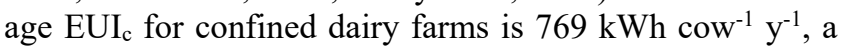
biodigester with manure as the only feedstock can cover the on-farm electricity requirements of most herds. Nelson and Lamb (2002) provide a case where the biodigester on a 750-milking-cow dairy is able to produce all its electricity needs as well as generate a surplus able to power roughly 75 homes. In addition, excess heat from the biodigester could be used to heat water and spaces. Economic analyses show that larger farms are best suited to biodigesters (e.g., $>2,600$ cows; Lauer et al. 2018); however, small scale operations are viable with sufficient incentives for renewables (e.g., case study of a 75 cow operation; IEA 2020).

Another option for generating electricity is photovoltaic solar panels. Net metering enables the dairy farm to use the grid as a no-cost storage system for times when the PV array produces more electricity than is needed on the farm. Louwen and van Sark (2020) show that there have been rapid price decreases for PV modules in the past (e.g., dropping over $90 \%$ from 2008 to 2018 ) and costs are forecast to continue decreasing in the coming decades. With these trends it is likely that PV electricity will be cost-competitive in many locations, even where irradiance is relatively low. Since dairy farms often have large barns, roof-mounted panels are a good fit and are less expensive to install than panels mounted on a ground-based racking system. Potential PV output can be estimated using the National Renewable Energy Laboratory calculator, PVWatts ${ }^{\circledR}$ (https://pvwatts.nrel. gov/pvwatts.php). Consider a 250-milking-cow herd housed in a $2,750 \mathrm{~m}^{2}$ barn with $50 \%$ of the roof being south-facing, located in eastern Ontario $\left(44.25^{\circ} \mathrm{N}, 75.82^{\circ} \mathrm{W}\right)$. This region has an average annual insolation of $4.37 \mathrm{kWh} \mathrm{m}^{-2} \mathrm{~d}^{-1}$. A $200 \mathrm{~kW}$ DC system on south-facing panels $\left(20^{\circ}\right.$ tilt $)$ would have the potential to produce roughly $240,000 \mathrm{kWh} \mathrm{y}^{-1}$ of electricity $\left(960 \mathrm{kWh} \mathrm{cow}^{-1} \mathrm{y}^{-1}\right)$. Based on the North American $\mathrm{EUI}_{\mathrm{c}}$ of confined dairies, this system would generate almost all the electricity that the farm is expected to consume. 
Table 6. Summary of models and decision support systems. ${ }^{[a]}$

\begin{tabular}{|c|c|c|c|}
\hline Source & Format & Scope & Notable Output(s) / Result(s) \\
\hline agSTAR handbook (US EPA, 2004) & $\begin{array}{l}\text { PDF document with preliminary screening } \\
\text { questionnaire to determine feasibility of } \\
\text { on-farm biogas generation }\end{array}$ & BG & $\mathrm{N} / \mathrm{A}$ \\
\hline $\begin{array}{l}\text { Validation of a biogas production } \\
\text { model and determination of thermal } \\
\text { energy from plug-flow anaerobic digesters. } \\
\text { (Gebremedhin and Inglis, 2007) }\end{array}$ & $\begin{array}{l}\text { Theoretical biogas production model } \\
\text { from peer reviewed paper }\end{array}$ & BG & Biogas production $\left(\mathrm{m}^{3} \mathrm{~d}^{-1}\right)$ \\
\hline $\begin{array}{c}\text { PVWatts }{ }^{\circledR}, \text { National Renewable } \\
\text { Energy Laboratory }\end{array}$ & $\begin{array}{c}\text { Photovoltaic electricity } \\
\text { production calculator } \\
\text { https://pvwatts.nrel.gov/pvwatts.php }\end{array}$ & PV & $\mathrm{kWh} \mathrm{mo}^{-1}$ \\
\hline $\begin{array}{l}\text { Dairy farm energy efficiency tool. } \\
\text { (EECA, 2020) }\end{array}$ & $\begin{array}{l}\text { Direct input into website text } \\
\text { fields (New Zealand only) }\end{array}$ & WF & $\begin{array}{l}\text { Potential savings from efficient } \\
\left.\text { technology ( } \mathrm{t} \mathrm{CO}_{2} \mathrm{e} \text { emissions }\right)\end{array}$ \\
\hline $\begin{array}{l}\text { Regression modelling of on-farm direct } \\
\text { water and electricity consumption on pas- } \\
\text { ture based dairy farms (Shine et al. 2018a) }\end{array}$ & $\begin{array}{l}\text { Electricity consumption linear regression } \\
\text { model from peer reviewed paper }\end{array}$ & WF & Electricity demand $\left(\mathrm{kWh} \mathrm{mo}^{-1}\right)$ \\
\hline $\begin{array}{l}\text { Dairy Energy Prediction (DEP) model: } \\
\text { A tool for predicting energy use } \\
\text { and related emissions and costs in } \\
\text { dairy farms. (Todde et al., 2017) }\end{array}$ & $\begin{array}{c}\text { Downloadable combined cost, energy, } \\
\text { and emission model (Microsoft Excel } \\
\text { format) from peer reviewed paper. } \\
\text { http://bit.ly/DEPTOOL }\end{array}$ & WF & $\begin{array}{l}\text { Electricity demand }(\mathrm{kWh}) \\
\text { EUIc }\left(\mathrm{kWh} \text { cow } \mathrm{y}^{-1}\right) \\
\text { EUIm }\left(\mathrm{kWh} 100 \mathrm{~kg}^{-1}\right)\end{array}$ \\
\hline $\begin{array}{c}\text { A mechanistic model for electricity } \\
\text { consumption on dairy farms: Definition, } \\
\text { validation, and demonstration. } \\
\text { (Upton et al., 2014a) }\end{array}$ & $\begin{array}{l}\text { Peer reviewed paper with component- } \\
\text { specific models for predicting energy } \\
\text { demand on dairy farms }\end{array}$ & $\begin{array}{l}\text { MC, H, L, } \\
\text { MS, MP, MH }\end{array}$ & Electricity demand (kWh) \\
\hline \multirow{2}{*}{$\begin{array}{c}\text { Modelling and benchmark development } \\
\text { for electrical energy use and energy } \\
\text { efficiency on NOVA SCOTIA dairy farms. } \\
\text { (Pradhanang, 2015) }\end{array}$} & \multirow[b]{2}{*}{$\begin{array}{l}\text { M.Sc. thesis with section on } \\
\text { modeling energy use on a } \\
\text { component-specific basis }\end{array}$} & $\mathrm{MC}$ & Heat removed $\left(\mathrm{MJ} \mathrm{d}^{-1}\right)$ \\
\hline & & $\begin{array}{l}\text { H, MS, L, } \\
\mathrm{MH}, \mathrm{FH}, \mathrm{CC}\end{array}$ & Electricity demand $\left(\mathrm{kWh} \mathrm{y}^{-1}\right)$ \\
\hline $\begin{array}{l}\text { USDA energy estimator version: } \\
2.2 .0 .623 \text { (USDA, 2019) }\end{array}$ & $\begin{array}{l}\text { Direct input into website text fields } \\
\text { to predict annual electricity demand } \\
\text { of dairy farm components. } \\
\text { Note: requires USA zip code. }\end{array}$ & $\begin{array}{l}\mathrm{MS}, \mathrm{MC}, \\
\mathrm{H}, \mathrm{L}, \mathrm{CC}\end{array}$ & Electricity demand $\left(\mathrm{kWh} \mathrm{y}^{-1}\right)$ \\
\hline
\end{tabular}

\section{MODELS AND DECISION SUPPORT SYSTEMS}

Various modeling tools are available to farm managers, policy makers, and researchers to estimate the electricity usage of a farm and inform decision making (see summary in table 6). The complexity ranges from simple tables of the expected electricity usage of typical farm equipment to comprehensive modeling studies. Similarly, the input data vary from a few general farm characteristics to detailed farm information. For example, the USDA (2019) energy estimator has input questions regarding energy saving technologies discussed in the previous section and provides users with annual monetary savings realized by converting to more efficient technologies. Some of these tools are designed for specific regions (EECA, 2020; USDA, 2019) or farm management types (Shine et al., 2018a).

\section{CONCLUSION}

The quantity of electricity required on dairy farms varies widely by farm management system, barn design, available technology, region, herd size, and irrigation (tables 1 and 2). Energy utilization indices $\left(\mathrm{EUI}_{\mathrm{c}}, \mathrm{EUI}_{\mathrm{m}}\right)$ can be used to characterize the importance of the dairy sector to local, regional and national energy policies. Considerable progress has been made to demonstrate conservation measures that can reduce electricity consumption and costs on dairy farms. The most impactful technologies include the installation of VSD for milk vacuum pumps and milk transfer systems as well as the installation of pre-cooling heat exchangers, RHR systems, energy-efficient light fixtures, and efficient ventilation systems. Electrical metering and submetering can be used to track usage patterns at the component and equipment level and to analyze and improve the energy efficiency of dairy farms. Monitoring could be used with a maintenance program to detect and prevent equipment problems. More work needs to be done to assess new and emerging technology from an energy efficiency point of view. With a better understanding of the impact of these technologies, better electricity use models can be created. By combining conservation technologies with renewable generation technologies (e.g., anaerobic digestion, solar), net zero electricity is within reach for many dairy operations. With the right combination of education, policy, and industry support, the dairy sector is well positioned to reduce its electricity demand and even be a net producer of renewable electricity.

\section{REFERENCES}

Alberta Government. (2014). Energy Efficiency on dairy farms. Aguirre-Villegas, H. A., Passos-Fonseca, T. H., Reinemann, D. J., \& Larson, R. (2017). Grazing intensity affects the environmental impact of dairy systems. J. Dairy Sci., 100(8), 6804-6821. https://doi.org/10.3168/jds.2016-12325

Allen, D. B., DePeters, E. J., \& Laben, R. C. (1986). Three times a day milking: Effects on milk production, reproductive efficiency, and udder health. J. Dairy Sci., 69(5), 1441-1446. https://doi.org/10.3168/jds.S0022-0302(86)80553-7 
Arsenault, N., Tyedmers, P., \& Fredeen, A. (2009). Comparing the environmental impacts of pasture-based and confinement-based dairy systems in Nova Scotia (Canada) using life cycle assessment. Int. J. Agric. Sustainability, 7(1), 19-41. https://doi.org/10.3763/ijas.2009.0356

Bailey, J. A., Duinker, P., Amyotte, P., Adams, M., \& Khan, F. (2016). Measuring energy conservation on Nova Scotia (NS) farms: A 2004 to 2011 comparison. Energy, 113, 144-152. https://doi.org/10.1016/j.energy.2016.06.140

Bailey, J. A., Gordon, R., Burton, D., \& Yiridoe, E. K. (2008). Energy conservation on Nova Scotia farms: Baseline energy data. Energy, 33(7), 1144-1154. https://doi.org/10.1016/j.energy.2008.02.010

Beard, R. (2012). Energy-efficient hot water for farms. Retrieved from https://farm-energy.extension.org/energy-efficient-hotwater-for-farms/

Belflower, J. B., Kiepper, B. H., Perry, J. C., Risse, L. M., \& Smith, R. C. (2012). Water and electricity consumption on pasturebased and confined dairies in Georgia. Appl. Eng. Agric., 28(2), 259-263. https://doi.org/10.13031/2013.41344

Bernabucci, U., Biffani, S., Buggiotti, L., Vitali, A., Lacetera, N., \& Nardone, A. (2014). The effects of heat stress in Italian Holstein dairy cattle. J. Dairy Sci., 97(1), 471-486. https://doi.org/10.3168/jds.2013-6611

Bickert, W. G., \& Light, R. G. (1982). Housing systems. J. Dairy Sci., 65(3), 502-508. https://doi.org/10.3168/jds.S00220302(82)82224-8

Biogas Association. (2013). Canadian Biogas Study - benefits to the economy, environment, and energy. Retrieved from https://biogasassociation.ca/images/uploads/documents/2014/bio gas_study/Canadian_Biogas_Study_Technical_Document_Dec_ 2013.pdf

Boadzo, A., Chowdhury, S. P., \& Chowdhury, S. (2011). Modeling and assessment of dairy farm-based biogas plants in South Africa. Proc. IEEE Power and Energy Society General Meeting, (pp. 1-8). https://doi.org/10.1109/PES.2011.6039181

Brinker, J. L., Reinholtz, B. J., Williams, B., \& Bergum, M. (2013). Dairy farm retro-commissioning: retrofit study of HVLS and tunnel ventilated barns. ASABE Paper No. 131595840. St. Joseph, MI: ASABE. https://doi.org/http://dx.doi.org/10.13031/aim.20131595840

Calcante, A., Tangorra, F. M., \& Oberti, R. (2016). Analysis of electric energy consumption of automatic milking systems in different configurations and operative conditions. J. Dairy Sci., 99(5), 4043-4047. https://doi.org/10.3168/jds.2015-10490

Capareda, S. C., Mukhtar, S., Engler, C., \& Goodrich, L. B. (2010). Energy usage survey of dairies in the southwestern United States. Appl. Eng. Agric., 26(4), 667-675. https://doi.org/10.13031/2013.32063

Canadian Dairy Information Center (CDIC). 2018. Dairy facts and figure. Online. Available at: https://www.dairyinfo.gc.ca/index_e.php?s1=dff-fcil (accessed June 12, 2019)

Cederberg, C., \& Flysjo, A. (2004). Life cycle inventory of 23 dairy farms in southwestern Sweden. Retrieved from https://pdfs.semanticscholar.org/b930/2a75bd2a17e4398ca3c880 927b7924d66911.pdf

CEIC. (2019). China electricity price. Retrieved from https://www.ceicdata.com/en/china/electricity-price

Christie, K. M., Gourley, C. J. P, Rawnsley, R. P., Eckard, R. J., \& Awty, I. M. (2012). Whole-farm systems analysis of Australian dairy farm greenhouse gas emissions. Animal Prod. Sci., 52(11), 998-1011. https://doi.org/10.1071/AN12061

Clarke, S. (2016). Farm lighting and energy incentives. Ontario Ministry of Agriculture, Food, \& Rural Affairs.
Clarke, S., \& House, H. A. (2006). Energy efficient dairy lighting fact sheet. Ontario Ministry of Agriculture, Food, \& Rural Affairs. Retrieved from http://www.omafra.gov.on.ca/english/engineer/facts/06-007.htm

Corscadden, K. W., Biggs, J. N., \& Pradhanang, M. (2014). Energy efficient technology selection for dairy farms: Milking cooling and electric water heating. Appl. Eng. Agric., 30(3), 375-382. https://doi.org/10.13031/aea.30.10403

Dahl, G. E., Buchanan, B. A., \& Tucker, H. A. (2000). Photoperiodic effects on dairy cattle: A review. J. Dairy Sci., 83(4), 885-893. https://doi.org/10.3168/jds.S00220302(00)74952-6

Delaby, L., Finn, J. A., Grange, G., \& Horan, B. (2020). Pasturebased dairy systems in temperate lowlands: Challenges and opportunities for the future. Frontiers Sustainable Food Syst., 4, 278. https://doi.org/10.3389/fsufs.2020.543587

DFC. (2017). Fact sheet: Cold-water wash. Dairy Farmers of Canada.

Dice, M. (2017). Net zero energy dairy production: Powering Minnesota dairy farms with renewable energy (Honors Capstone Project). University of Minnesota Morris Digital Wells. Retrieved from https://digitalcommons.morris.umn.edu/cgi/viewcontent.cgi?arti cle $=1006 \&$ context $=$ honors

Dyer, J. A., \& Desjardins, R. L. (2006). An integrated index of electrical energy use in canadian agriculture with implications for greenhouse gas emissions. Biosyst. Eng., 95(3), 449-460. https://doi.org/10.1016/j.biosystemseng.2006.07.013

Ebinger, F. (2015). Dairy energy efficiency - Dairy cooperative partnerships for improved efficiency program adoption. Minnesota Dept of Commerce, Div. of Energy Resources. Retrieved from http://mn.gov/commerce-stat/pdfs/card-reporttmp-dairy-ee.pdf

Edens, W. C., Pordesimo, L. O., Wilhelm, L. R., \& Burns, R. T. (2003). Energy use analysis of major milking center components at a dairy experiment station. Appl. Eng. Agric., 19(6), 711-716. https://doi.org/10.13031/2013.15659

EECA. (2009). Case study: Dairy farmers milk free energy. Energy Efficiency and Conservation Authority. Retrieved from https://www.solarthermalworld.org/story/case-study-dairyfarmers-milk-free-energy-2009

EECA. (2020). Dairy farm energy efficiency tool. Energy Efficiency and Conservation Authority. Retrieved from https://tools.genless.govt.nz/businesses/dairy-farm-energyefficiency-tool/

El-Mashad, H. M., \& Zhang, R. (2006). Anaerobic codigestion of food waste and dairy manure. ASABE Paper No. 066161. St. Joseph, MI: ASABE. https://doi.org/10.13031/2013.21522

EnSave. (2015). Energy efficiency in New York State agriculture: Summary of energy efficiency programs and research opportunities. New York State Energy Research and Development Authority.

Eurostat. (2018). Agri-environmental indicator - energy use. Retrieved from https://ec.europa.eu/eurostat/statisticsexplained/index.php/Agri-environmental_indicator__energy_use

Eurostat. (2019). Electricity price statistics. Retrieved from https://ec.europa.eu/eurostat/statisticsexplained/index.php/Electricity_price_statistics

FAO. (2006). World agriculture: Towards 2030/2050. Rome, Italy: United Nations FAO. Retrieved from http://www.fao.org/fileadmin/user_upload/esag/docs/Interim_re port_AT2050web.pdf

FAO. (2011). World livestock 2011, livestock in food security. Rome, Italy: United Nations FAO. Retrieved from http://www.fao.org/docrep/014/i2373e/i2373e00.htm 
FAO. (2020). Dairy market review - Overview of global dairy market developments in 2019. Rome, Italy: United Nations FAO. Retrieved from http://www.fao.org/publications/card/en/c/ca8341en/

FarmEnergy Nova Scotia. (2017). Refrigeration heat recovery fact sheet. Retrieved from https://nsefp.ca/wpcontent/uploads/2017/03/FENS_factsheet_refrigeration_heat_re covery.pdf

Figure.nz. (2019). Domestic electricity prices in New Zealand towns and cities. Retrieved from https://figure.nz/chart/Kx2boXoRyZYpLWBb

Flemmer, C. (2012). Environmental input-output analysis of the New Zealand dairy industry. Int. J. Sustainable Dev., 15(4), 313333. https://doi.org/10.1504/IJSD.2012.050030

Galan, F., Dolle, J. B., Charroin, T., Ferrand, M., \& Hiet, C. (2007). Consommation d'énergie en élevage bovin - Des repères pour se situer et progresser. Renc. Rech. Rum, 14, 29-32.

Gebremedhin, K. G., \& Inglis, S. F. (2007). Validation of a biogas production model and determination of thermal energy from plug-flow anaerobic digesters. Trans. ASABE, 50(3), 975-979. https://doi.org/10.13031/2013.23137

Gentilini, M. B., \& Lopez-Benavides, M. (2014). Case report: Cleaning efficacy of a chlorinated alkaline detergent for reduced temperatures in milking systems. Proc. NMC Annual Meeting, (pp. 187-188).

Gould, M. C., \& Go, A. S. (2015). Increase milk production and reduce energy consumption with long day lighting. Retrieved from

https://www.canr.msu.edu/news/increase_milk_production_and reduce_energy_consumption_with_long_day_lighti

Grace, I., Datta, D., \& Tassou, S. A. (2002). Comparison of hermetic scroll and reciprocating compressors operating under varying refrigerant charge and load. Paper No. 1518. Presented at International Compressor Engineering Conf. West Lafayette, IN: Purdue University. Retrieved from https://docs.lib.purdue.edu/cgi/viewcontent.cgi?article $=2517 \&$ co ntext $=$ icec

Hinck, T. (2018). Whole-farm energy management - Applying realtime energy monitoring techniques to agriculture sites. Retrieved from http://mn.gov/commerce-stat/pdfs/card-report-whole-farmenergy.pdf

House, H. K., Hawkins, B. C., \& Barkes, B. C. (2014). Measuring and characterizing on-farm milking centre washwater volumes. ASABE Paper No. 141908138. St. Joseph, MI: ASABE. https://doi.org/10.13031/aim.20141908138

Houston, C., Gyamfi, S., \& Whale, J. (2014). Evaluation of energy efficiency and renewable energy generation opportunities for small scale dairy farms: A case study in Prince Edward Island, Canada. Renewable Energy, 67, 20-29.

https://doi.org/10.1016/j.renene.2013.11.040

HydroQuebec. (2018). Comparison of electricity prices in major North American cities. Retrieved from http://www.hydroquebec.com/data/documentsdonnees/pdf/comparison-electricity-prices.pdf

IEA. (2020). Compact and automated on-farm biogas production in southwestern Ontario, Canada. International Energy Agency. Retrieved from https://www.ieabioenergy.com/wpcontent/uploads/2020/05/IEA_canada_LAY_NEW1_green.pdf

Kammel, D. W., \& Patoch, J. (1993). Energy savings achieved from heat recovery systems. Trans. ASAE, 36(4), 1211-1215. https://doi.org/10.13031/2013.28452

Khakbazan. (2000). Descriptive analysis of on-farm energy use in Canada. Report No. EDB-00:023656. Natural Resources Canada.
Kraatz, S. (2012). Energy intensity in livestock operations Modeling of dairy farming systems in Germany. Agric. Syst., 110, 90-106. https://doi.org/10.1016/j.agsy.2012.03.007

Lauer, M., Hansen, J. K., Lamers, P., \& Thran, D. (2018). Making money from waste: The economic viability of producing biogas and biomethane in the Idaho dairy industry. Appl. Energy, 222, 621-636. https://doi.org/10.1016/j.apenergy.2018.04.026

Louwen, A., \& van Sark, W. (2020). Chapter 5 - Photovoltaic solar energy. In M. Junginger, \& A. Louwen (Eds.), Technological learning in the transition to a low-carbon energy system (pp. 6586). Academic Press. https://doi.org/10.1016/B978-0-12818762-3.00005-4

Ludington, D., \& Johnson, E. L. (2003). Dairy farm energy audit summary. New York State Energy Research and Development Authority. Retrieved from http://www.nyserda.ny.gov//media/Files/Publications/Research/Energy-Audit-Reports/dairyfarm-energy.pdf

Ludington, D., Johnson, E. L., Kowalski, J., Magem, A., \& Peterson, R. (2004). Dairy farm energy efficiency guide. Ithaca, NY: DLTech, Inc.

Marszal, A. J., Heiselberg, P., Bourrelle, J. S., Musall, E., Voss, K., Sartori, I., \& Napolitano, A. (2011). Zero energy building: A review of definitions and calculation methodologies. Energy Build., 43(4), 971-979. https://doi.org/10.1016/j.enbuild.2010.12.022

Mehta, A. (2002). The economics and feasibility of electricity generation using manure digesters on small and mid-size dairy farms [abstract]. https://doi.org/10.2139/ssrn.2638078

Meul, M., Van Passel, S., Fremaut, D., \& Haesaert, G. (2012). Higher sustainability performance of intensive grazing versus zero-grazing dairy systems. Agron. Sustainable Dev., 32(3), 629-638. https://doi.org/10.1007/s13593-011-0074-5

Minott, S. J., \& Scott, N. R. (2001). Feasibility of fuel cells for energy conversion on dairy farms. ASAE Paper No. 017015. St. Joseph, MI: ASAE. https://doi.org/10.13031/2013.7508

Murgia, L., Caria, M., \& Pazzona, A. (2008). Energy use and management in dairy farms. Proc. Int. Conf. on Innovation Technology to Empower Safety, Health and Welfare in Agriculture and Agro-food Systems. Retrieved from www.ragusashwa.it/CD_2008/lavori/TOPIC9/orale/MURGIA.p df

Murgia, L., Todde, G., Caria, M., \& Pazzona, A. (2013). A partial life cycle assessment approach to evaluate the energy intensity and related greenhouse gas emission in dairy farms. J. Agric. Eng., 44(2s). https://doi.org/10.4081/jae.2013.279

Murphy, M. D., Upton, J., \& O’Mahony, M. J. (2013). Rapid milk cooling control with varying water and energy consumption. Biosyst. Eng., 116(1), 15-22. https://doi.org/10.1016/j.biosystemseng.2013.05.007

Nacer, T., Hamidat, A., \& Nadjemi, O. (2016). A comprehensive method to assess the feasibility of renewable energy on Algerian dairy farms. J. Cleaner Prod., 112, 3631-3642. https://doi.org/10.1016/j.jclepro.2015.06.101

Nelson, C., \& Lamb, J. (2002). Final report: Haubenschild farms anaerobic digester (The Minnesota Project). Retrieved from https://www.cleanenergyresourceteams.org/sites/default/files/pu blication_files/Haubyrptupdated.pdf

NRCan. (2019). Electricity facts. Natural Resources Canada. Retrieved from https://www.nrcan.gc.ca/electricity-facts/20068

OMAFRA. (2011). Planning dairy operation feeding systems for expansion fact sheet. Ontario Ministry of Agriculture, Food and Rural Affairs. Retrieved from http://www.omafra.gov.on.ca/english/livestock/dairy/facts/11051w.htm 
OMAFRA. (2016). Energy yields from a farm-based anaerobic digestion system factsheet. Ontario Ministry of Agriculture, Food and Rural Affairs. Retrieved from

http://www.omafra.gov.on.ca/english/engineer/facts/enyields.htm

Ors, A., \& Oguz, C. (2018). Comparison of the economic performance of robotic milking system and conventional milking system. Manas J. Agric. Vet. Life Sci., 8(2), 35-51.

Peebles, R. W., Reinemann, D. J., \& Straub, R. J. (1994). Analysis of milking center energy use. Appl. Eng. Agric., 10(6), 831-839. https://doi.org/10.13031/2013.25918

Pervanchon, F., Bockstaller, C., \& Girardin, P. (2002). Assessment of energy use in arable farming systems by means of an agroecological indicator: The energy indicator. Agric. Syst., 72(2), 149-172. https://doi.org/10.1016/S0308-521X(01)00073-7

Podstolski, M. (2016). The evolution of total energy inputs in the New Zealand dairy industry. MS thesis. Christchurch, NZ: Lincoln University.

Pradhanang, M. P. (2015). Modelling and benchmark development for electrical energy use and energy efficiency on Nova Scotia dairy farms. MS thesis. Halifax, Canada: Dalhousie University. Retrieved from http://hdl.handle.net/10222/56308

Pressman, A. (2010). Dairy farm energy efficiency. Retrieved from https://parasitology.cvm.ncsu.edu/vmp991/dairy/supplement/dai ry_energy.pdf

Purdy, A., Pathare, P. B., Wang, Y., Roskilly, A. P., \& Huang, Y. (2018). Towards sustainable farming: Feasibility study into energy recovery from bio-waste on a small-scale dairy farm. $J$. Cleaner Prod., 174, 899-904. https://doi.org/10.1016/j.jclepro.2017.11.018

Rajaniemi, M., Jokiniemi, T., Alakukku, L., \& Ahokas, J. (2017). Electric energy consumption of milking process on some Finnish dairy farms. Agric. Food Sci., 26(3), 160-172. https://doi.org/10.23986/afsci.63275

Rivas-Garcia, P., Botello-Alvarez, J. E., Abel Seabra, J. E., da Silva Walter, A. C., \& Estrada-Baltazar, A. (2015). Environmental implications of anaerobic digestion for manure management in dairy farms in Mexico: A life cycle perspective. Environ. Technol., 36(17), 2198-2209. https://doi.org/10.1080/09593330.2015.1024758

Sanford, S. (2003a). Ventilation and cooling systems for animal housing. Publ. No. A3784-6. University of WisconsinCooperative Ext. Retrieved from https://learningstore.uwex.edu/Assets/pdfs/A3784-06.pdf

Sanford, S. (2003b). Well water precoolers. Publ. No. A3784-3. University of Wisconsin-Cooperative Ext. Retrieved from https://learningstore.uwex.edu/Assets/pdfs/A3784-03.pdf

Schnepf, R. (2004). Energy use in agriculture: Background and issues. Report Code RL32677. National Agricultural Law Center. Retrieved from https://nationalaglawcenter.org/wpcontent/uploads/assets/crs/RL32677.pdf

Shine, P., Scully, T., Upton, J., \& Murphy, M. D. (2018a). Multiple linear regression modelling of on-farm direct water and electricity consumption on pasture based dairy farms. Comput. Electron. Agric., 148, 337-346. https://doi.org/10.1016/j.compag.2018.02.020

Shine, P., Scully, T., Upton, J., Shalloo, L., \& Murphy, M. D. (2018b). Electricity \& direct water consumption on Irish pasture based dairy farms: A statistical analysis. Appl. Energy, 210, 529537. https://doi.org/10.1016/j.apenergy.2017.07.029

Shortall, J., O’Brien, B., Sleator, R. D., \& Upton, J. (2018). Daily and seasonal trends of electricity and water use on pasture-based automatic milking dairy farms. J. Dairy Sci., 101(12), 15651578. https://doi.org/10.3168/jds.2017-13407
Slocombe, J. W., Feyerherm, A. M., \& Stetson, L. E. (1992). Energy usage on Kansas livestock and dairy farms. Appl. Eng. Agric., 8(3), 389-392. https://doi.org/10.13031/2013.26082

Stinson, J. W. (2015). Smart energy monitoring technology to reduce domestic electricity and gas consumption through behaviour change. PhD diss. Scotland: Edinburgh Napier University.

Todde, G., Murgia, L., Caria, M., \& Pazzona, A. (2017). Dairy Energy Prediction (DEP) model: A tool for predicting energy use and related emissions and costs in dairy farms. Comput. Electron. Agric., 135, 216-221.

https://doi.org/10.1016/j.compag.2017.02.014

United Nations. (2017). World population prospects. Retrieved from

https://esa.un.org/unpd/wpp/publications/Files/WPP2017_KeyFi ndings

Upton, J., Humphreys, J., Groot Koerkamp, P. W., French, P., Dillon, P., \& De Boer, I. J. (2013). Energy demand on dairy farms in Ireland. J. Dairy Sci., 96(10), 6489-6498. https://doi.org/10.3168/jds.2013-6874

Upton, J., Murphy, M. D., Groot Koerkamp, P. W., Shalloo, L., \& De Boer, I. J. (2014b). Strategies to reduce energy use in dairy milking facilities. ASABE Paper No. 141893559. St. Joseph, MI: ASABE. https://doi.org/10.13031/aim.20141893559

Upton, J., Murphy, M., De Boer, I. J., Groot Koerkamp, P. W., Berentsen, P. B., \& Shalloo, L. (2015). Investment appraisal of technology innovations on dairy farm electricity consumption. $J$. Dairy Sci., 98(2), 898-909. https://doi.org/10.3168/jds.20148383

Upton, J., Murphy, M., Shalloo, L., Groot Koerkamp, P. W., \& De Boer, I. J. (2014a). A mechanistic model for electricity consumption on dairy farms: Definition, validation, and demonstration. J. Dairy Sci., 97(8), 4973-4984. https://doi.org/10.3168/jds.2014-8015

USDA. (2017). Milk production. Washington, DC: USDA. USDA. (2019). Energy estimator: Animal housing. Washington, DC: USDA. Retrieved from https://ahat.sc.egov.usda.gov/

USEPA. (2004). AgSTAR project development handbook. Washington, DC: USEPA. Retrieved from https://www.epa.gov/sites/production/files/201412/documents/agstar-handbook.pdf

Wang, X., Kristensen, T., Mogensen, L., Knudsen, M. T., \& Wang, X. (2016). Greenhouse gas emissions and land use from confinement dairy farms in the Guanzhong plain of China using a life cycle assessment approach. J. Cleaner Prod., 113, 577-586. https://doi.org/10.1016/j.jclepro.2015.11.099

Wang, X., Ledgard, S., Luo, J., Guo, Y., Zhao, Z., Guo, L., ... Ma, L. (2018). Environmental impacts and resource use of milk production on the North China Plain, based on life cycle assessment. Sci. Total Environ., 625, 486-495. https://doi.org/10.1016/j.scitotenv.2017.12.259

Wells, C. (2001). Total energy indicators of agricultural sustainability: Dairy farming case study. Technical paper. Wellington, NZ: Ministry of Agriculture and Forestry.

Yiridoe, E. K., Gordon, R., \& Brown, B. B. (2009). Nonmarket cobenefits and economic feasibility of on-farm biogas energy production. Energy Policy, 37(3), 1170-1179. https://doi.org/10.1016/j.enpol.2008.11.018

Zhang, C., Campana, P. E., Yang, J., Yu, C., \& Yan, J. (2018). Economic assessment of photovoltaic water pumping integration with dairy milk production. Energy Convers. Manag., 177, 750764. https://doi.org/10.1016/j.enconman.2018.09.060 